\title{
SASAT Bisise Hal: 63-70 \\ PUTTING ORGANIZATIONAL STUDIES IN INDONESIA INTO THE RIGHT TRACK: DIALECTIC BETWEEN POSITIVISM AND INTERPRETIVISM
}

\author{
Arif Hartono \\ Faculty of Economics \\ Universitas Islam Indonesia \\ e-mail: arifhartono@yahoo.com orarif-htn@uii.ac.id
}

\begin{abstract}
Positivism-quantitative has been well known many years as research mainstream on organizational studies in Indonesia. However, the implementation of positivism-quantitative approaches was not utilized appropriately. It is reasonable because these approaches were born in western society and culture, which is so difference with Indonesian one. Based on this argument, the implementation of interpretive-constructive-qualitative approaches for exploring and investigating Indonesian cases would be better since it is more appropriate for Indonesian organizational life.
\end{abstract}

Keywords: positivism, interpretivism, social differences, cultural differences, Indonesian model.

\section{INTRODUCTION}

This is a fact that organizational researches have been dominated by positivistquantitative approaches (see such as Audet et al. 1986; Behling, 1980; Burrell \& Morgan, 1979; Lincoln, 1985; and Rorty, 1987). It is because positivist-functionalist paradigm (or as Kuhn, 1970; said as "normal science' paradigm) has been accepted and well-known among organization's scholars as a popular approach to investigate organizational phenomena. Another reason, theoretical foundation of organizational studies has been constructed for a long period in Western so further researches tends to validate previous findings rather than developing a new school of thought.

Unfortunately, we have to say sadly that the same phenomena have been happening in Indonesia whereas it has very different background, especially social and culture (see such as Hampden-Turner \& Trompenaars, 2000; Hofstede, 2001; Trompenaars, 1993). Furthermore, theoretical foundation of organizational studies within Indonesian context also has not constructed very well yet. In this sense, very essential questions could be revealed: Is the positivist-quantitative methodology can be determined as the best approach to investigate organizational phenomena within Indonesian context? Should we always follow the Western style of organizational theories in researching Indonesian organizations? Are there any other approaches that more suitable to investigate the Indonesian organization phenomena?

This paper tries to melt an ice mountain' of assumption among Indonesian scholars which tend to place the positivistquantitative as the most valid, reliable, or even the best methodology in examining the Indonesian organizational phenomena. Moreover, the paper promotes interpretiveconstructivist-qualitative approaches as an alternative or even a better methodology to construct an Indonesian model of an organ- 
izational theory which could be different from Western.

\section{Designing Organizational Studies}

Designing research, including organizational studies, is not a simple process because involves a number of related stages (Burrell \& Morgan, 1979; Creswell, 2003 \& 1994; Crotty, 1998; Denzin \& Lincoln, 2000; Sarantakos, 1998; Neuman, 2003). Unfortunately, scholars (such as Blaiki, 2000; Bogdan \& Taylor, 1975; Rocco, 2003; Yin, 1989, 1994, 2003) indicated that quite often researchers demonstrate a lack of awareness that there is a need to provide a rationale behind research design selected.

In term of Indonesian phenomenon, we have no difficulties to find many organizational studies that published in Indonesian business-management journals express the generalisation above. Most of them declared that they employed quantitative methodology or actually only describe a research method; unfortunately they did not mention the reasons why they should employee it. They tend to simplify research process by jumping into explanation of research methodology or even just a research method; lack of discussion about philosophical underpinning of research, namely paradigm, whereas this term has a fundamental role and determined the research process as a whole. Firestone (1990) argued "paradigm assumptions determine research strategy" or as Lincoln (1990) stated: "The adoption of a paradigm literally permeates every acts even tangentially associated with inquiry".

Burrell \& Morgan (1979), Crotty (1998), Creswell (1994, 2003), and Sarantakos $(1998,2005)$ underlined that research process can be determined into three compulsory stages. This process is begun by determining the most suitable paradigm including ontology and epistemology- for the study; followed by selection of research methodology and then finalized by choosing the research method to collect and analyse the data. It can be said clearly that methodology and method are continuous process beyond research paradigm selected. Accordingly, it is a compulsory for researchers to describe in what paradigm their study will be placed.

Sarantakos (1998:31) defined paradigm as: "...a set of propositions that explain how the world is perceived; it contains a world view, a way of breaking down the complexity of the real world, telling researcher and social scientists in general "what is important, what is legitimate, what is reasonable." Based on paradigm selected, methodology can be break down accordingly. In this term, methodology means "a model, which entails theoretical principles as well as a framework that provides guidelines about how research is done in the context of a particular paradigm" (Sarantakos, 1998). It means that a methodology should be able to translate the research paradigm selected into a set of principles that show how the subject being studied can be approached, explored and explained. As the final stage, researcher should be able to identify and choose the most suitable research method for data gathering and data analysing based upon paradigm and methodology determined.

Based on descriptions above, it can be said clearly that research design describes each step from the whole process of research; not only telling a methodology or even research method. Creswell (1998) described research design as entire process of research from conceptualizing a problem to writing the narrative. While Yin (1989) said that a research design is an action plan from here to there. Blaiki (2000), moreover, described that the main purposes of research design are: to make the research design decision explicit; to ensure that the decisions are consistent with each other and with onto- 
logical assumption adopted; and to allow for critical evaluation of the individual design elements, and the overall research design, before significant work commences.

\section{Between Positivist and Interpretive Para- digm}

As described earlier, the paradigm has an essential role in the research process. It is not surprisingly that researchers have to decide in which paradigm their research will be relied on. It means selecting paradigm is the first compulsory stage should be done by every researcher. Accordingly, researchers have to understand very well the term of paradigm, both philosophically and operationally.

In the simplest term, a paradigm refers to a fundamental view or broad view of life that affects the way particular aspects of reality are understood (Burrell \& Morgan, 1979). The paradigm is the general perspective or way of thinking that reflects fundamental beliefs and assumptions made about the nature of something (Kuhn, 1970). Similarly, Guba (1990), Guba \& Lincoln (1994), and Lincoln \& Guba (2000) emphasized that paradigm is a set basic beliefs (metaphysics) which positioned as ultimate or first principles in understanding the worldview of life. It means that the paradigm has an essential role to shapes the research at its most basic level (Burrell \& Morgan, 1979; Crotty, 1998; Guba, 1990; Patton, 1990, 2000; Sarantakos; 1998, 2005). In other words, research paradigm defines how researchers view the world, how they relate to the object studied, and what they see as the nature of reality.

Many scholars (such as Burrell \& Morgan, 1979; Crotty, 1998; Creswell, 1998; Guba, 1990, Guba \& Lincoln,1994; Hughes \& Sharrock, 1997, Lincoln \& Guba, 2000; May, 2001; Merriam, 1998; Neuman, 2003; Patton, 1990; Ruane, 2005; Sarantakos, 1998, 2005), basically agreed that there are two main paradigms in the social research, they are positivism (or as Burrell \& Morgan call functional) and interpretive (or Guba \& Lincoln called as constructivism).

Sarantakos (1998) mentioned that positivist identifies reality of social world is 'out there', real, objective, measurable, independent of human consciousness, rests on order, governed by strict, natural and unchangeable laws, and can be understand through experience. Because of reality can be perceived through the sense; positivists believe that all members of society perceive reality in the similar way because they all share the same meaning. In contrast, interpretive describes reality is not objective but what people see it is to be. Reality is in the mind of people -not out there-, internally experienced, socially constructed through interaction and interpreted through the actors.

Burrell and Morgan (1979), moreover, explained that the positivist (functional) seeks to provide essentially rational explanation of social affairs; it is characterized by an objective point of view. Hence, this approach tends to be realist, positivist, determinist and nomothetic. In contrast, interpretive paradigm concerns to understand the fundamental nature of the social world; it uses more subjective approach to analyse the social world. It is not surprisingly that this paradigm tends to be nominalist, antipositivist, voluntarist and ideographic.

Burrell and Morgan (1979) emphasized that in the interpretive paradigm, the meaning of reality is constructed by lived experience; multiple realities a constructed socially by individuals. Accordingly, understanding of the process or experience constitutes the knowledge to be gained from an inductive, hypothesis -or theory-generating mode of inquiry rather than a deductive or testing theory as the main prototype of positivist paradigm (also see Creswell, 2003; Crotty, 1998; Guba, 1990; Guba \& Lincoln, 
1994; Lincoln \& Guba, 2000; Sarantakos, 1998, 2005).

Interpretivists belief that life is selfreferential, and 'things' or events are what the mind makes of them (Tsoukas, 1998). In this way, events are viewed as dynamic and change our opinions as they unfold, to influence our understanding and interpretation (Schwandt, 2000). To be able to understand, the researcher needs to explore the subjective meaning. Remenyi et al. (1998) underlined interpretive is based on understanding "the details of the situation, to understand the reality or perhaps the reality working behind them".

Working under interpretive paradigm means the researchers need to analyse the world as a 'socio-psychological series', despite the relationship the researcher forms with participants, to ensure the subject can be fully explored (Lincoln and Guba, 2000). To achieve this, Glasser (1992) emphasized that researchers must have sufficient knowledge of the research area so they are able to interpret phenomena systematically.

When researching organizational phenomena within interpretive paradigm, the focus of the study is to interpret respondents' meaning relating to the organizational phenomena. Consequently, the study does not concern with quantification but with understanding the phenomena from the viewpoints of those experiencing organizational practices as Guba and Lincoln (1998) underlined: "human behaviour, unlike that of physical objects, cannot be understood without references to the meaning and purposes attached by the human actors to their activities".

\section{Constructing an Indonesian Model}

As mentioned before, positivistfunctionalist or popular as quantitative research is a dominant approach in investigating organizational phenomena, including in Indonesia. By utilizing positivist- functionalist paradigm, researchers assume that the nature of organizations is objective, 'out there', and can be explored as a single meaning (Burrell \& Morgan, 1979; Guba, 1990; Guba \& Lincoln, 1994; Lincoln \& Guba, 2000; Sarantakos, 1998, 2005). In other words, the meaning of realities can be captured straight forward, simpler, and do not need to find out the hidden meanings behind something. Hence, researchers tend to employ a deductive approach by proposing appropriate hypotheses about the organizational world and then testing them using statistical analysis. It is not surprisingly when Gioia \& Pitre (1990) mentioned that "the functionalist paradigm is characterized by an objective view of the organizational world with an orientation toward stability or maintained the status quo".

The positivist-functionalist approach become problematic since organizations also can be viewed as complex structure of organism (Morgan, 1997) which constantly changes overtime. An organization is a multifaceted social construct with a complex interaction internally and externally. To be survived, an organization has to follow the flow of changes by interaction and adaptation with their dynamic social environment. Since then, the existence of social facts and assumptions of stability are called into doubt. The assumptions that the nature of organizations is objective, 'out there', and can be explored as a single meaning have been challenged by new believe that nature of organizations is subjective, 'in here', and consists of multiple realities (Burrell \& Morgan, 1979; Guba, 1990; Guba \& Lincoln, 1994; Lincoln \& Guba, 2000; Sarantakos, 1998). Interpretivists consider the meaning of the nature depends on what the organizations' members think, feel, experienced, understood, interpret and construct the fact of realities; not framed by researchers. Remeny et al. (1998) underlined that interpretive seeks to understand "the details 
of the situation, to understand the reality or perhaps the reality working behind them".

When Indonesian scholars realized that organization is a multifaceted social construct, they will be aware that Indonesian organizational phenomena should be analysed more independently, not completely rely on the western organizational patterns. Moreover, they need to promote an Indonesian model which more reasonable and applicable in the Indonesian context. Since the natures of questions posed for organizational studies are in the Indonesian environment, they need to be constructed in a way that is relevant to the prevailing societal constructs (Crotty, 1998; Creswell, 2003; Guba \& Lincoln, 2000; Sarantakos, 2005). In other words, the answers of the research questions must be discovered through what is constructed by the organization's members itself. This approach allowed the organization's members to construct answers that are relevant to that subject being studied based on what they think, feel and experienced as Firestone (1987: 16) said "reality is socially constructed through individual or collective definitions of the situation". Thus, Indonesian scholars should be more confident to promote organizational construct based on the Indonesian atmosphere itself, not always as followers of Western doctrines. When researching phenomena that theoretically have not been well develop yet (such us organizational studies in Indonesia), the most suitable approach is to discover and delineate that phenomena have been practiced by Indonesian organizations not by Western organizations.

Constructivist is a quest to understand the construction and reconstructions that people hold (including the inquirer), before and during research activity (Guba and Lincoln, 1994). This approach allowed reinterpreting and reconstructing of data in a contextual setting. Moreover, Lincoln and Guba (2000) also Bradley and Schaefer
(1998) pointed out that they do not believe that evaluation standards of reality and validity are absolute, but tend to be derived from community consensus considering what is reality, what is useful, and what has meaning; there are multiple personally and socially constructed versions of reality. More completely, Guba and Lincoln (1989) described: Realities are apprehendable in the form of multiple, intangible mental construction, socially and experientially based, local in specific in nature (although elements are often shared among many individuals and even cross cultures), and dependent for their form and content on the individual persons or group holding the constructionstuctivism occurs when we interpret and use our knowledge to construct a meaningful reality out of the interactions between human beings and their world (Crotty, 1998). Such an approach recognizes that this reality is developed and transmitted within specific social contexts. Therefore, depending on the situation and context, there can be multiple constructions or views of reality (Creswell, 1998; Whiteley, 2002). This is quite different to the approach taken in quantitative studies, where the ontological assumption is that there are single realities. Therefore, constructivist will concentrate on the reality constructed by the participants involved in the research situation, rather than building on apriori knowledge or theory.

When researching organizational phenomena that theoretically have not been well develop yet, the most suitable approach is to discover and delineate that phenomena have been practiced by Indonesian organizations. Moreover, Lee (1999), Martin and Turner (1986) mentioned that the construction of organizational theory that grounded in data (not completely rely on existing theory) is more important to management scientists because of its broad applicability to many organizations issues and sheer preva- 
lence (also see Cassell \& Symons, 1994; Goulding, 2002)

\section{Closing Words}

Constructing an Indonesian model of organizational studies is a challenge for Indonesian scholars. Interpretive-constructivist approaches make the Indonesian scholars possible to develop organizational theories which grounded in Indonesian setting so they will be more valuable and applicable. Methodologically, interpretive-constructive has been well accepted among scholars across the globe so Indonesian scholars do not hesitate to utilize it.

\section{REFERENCES}

Audet, M., Landry, M., \& Dery, R. (1996). Sciene and Problem Solving: similarities, Dissimilarities, and Extensions in the Field of Administration Science. Philosophy of the Social Science, 16: 409-440.

Blaiki, N. (2000). Designing Social Research. Cambridge, UK: Polity Press.

Bradley, J., \& Schaefer, K. (1998). The Uses and Misuses of Data and Model. Thousand Oaks, CA: Sage.

Behling, O. (1980). The Case for the Natural Science Model for Research in Organizational Behavior and Organization Theory. Academy of Management Review, 5: 483-490.

Bogdan, R., \& Yaylor, S. (1975). Introduaction to Qualitative Research Methods. New York: John Wiley.

Burrell, G., \& Morgan, G. (1979). Sociological Paradigms and Organizational Analysis. London: Heinemann.

Cassell, C., \& Symon, G. (1994a). Qualitative research in work contexts, in
C. Casell \& G. Symon (Eds.). Qualitative Methods in Organizational Research: A Practical Guide. Pp. 1-13. Thousand Oaks, CA: Sage.

Cassell, C., \& Symon, G. (1994b). Qualitative Methods in Organizational Research: A Practical Guide. Thousand Oaks, CA: Sage.

Creswell, J.W. (1994). Research Design: Qualitative and Quantitative Approaches. Thousands Oaks, CA: Sage.

Creswell, J.W. (1998). Qualitative Enquiry and Research Design: Choosing among Five Traditions. Thousand Oaks, CA: Sage.

Creswell, J.W. (2003). Research Design: Qualitative, Quantitative and Mixed Methods Approaches $\left(2^{\text {nd }}\right.$ ed.). Thousand Oaks, CA: Sage.

Crotty, M. (1998). The foundations of social research: Meaning and perspective in the research process. St Leonards: Allen \& Unwin.

Denzin, N.K., \& Lincoln, Y.S. (2000). The Discipline and Practice of Qualitative Research. In N.K. Denzin \& Y.S. Lincoln (Eds.). Handbook of Qualitative Research. Pp. 1-28. Thousand Oaks, CA: Sage.

Denzin, N.K., \& Lincoln, Y.S. (2000), Handbook of Qualitative Research. Thousand Oaks, CA: Sage.

Firestone, W. (1987). Meaning in Method: The Rhetoric of Quantitative and Qualitative Research. Educational Researcher, 16(7), 16-21.

Firestone, W. (1990). Accomodation: Toward a Paradigm-Praxis Dialectic. In E.G. Guba (Ed). Paradigm Dia- 
log. Pp. 105-124. Thousand Oaks, CA: Sage.

Gioia, D.A., \& Pitre, E. (1990). Multiparadigm Perspectiva on Theory Building. Academy of Management Review, 15(4), 584-602.

Glaser, B.G. (1992). Basics of Grounded Theory analysis: Emergence vs. Forcing. Mill Valley: Sociology Press.

Goulding, C. (2002). Grounded Theory: A Practical Guide for Management, Business and Market Researcher. London: Sage

Guba, E.G. (1990). The Alternative Paradigm Dialog. In E.G. Guba (Ed). The paradigm dialog (17-27). Thousand Oaks, CA: Sage.

Guba, E.G., \& Lincoln, Y.S. (1989). Fourth Generation Evaluation. Beverly Hills: Sage.

Guba, E.R., \& Lincoln, Y.S. (1994). Competing Paradigms in Qualitative Research. In N.K. Denzin \& Y.S. Lincoln (Eds.). Handbook of Qualitative Research (105-117). Thousand Oaks, CA: Sage.

Guba, E.R., \& Lincoln, Y.S. (1998). Competing Paradigms in Qualitative Research. In N.K. Denzin \& Y.S. Lincoln (Eds.). The Landscape of Qualitative Research: Theories and Issues (195-220). Thousand Oaks, CA: Sage.

Guba, E.R., \& Lincoln, Y.S. (2000). Paradigmatic Controversies, Contradictions, and Emerging Confluences. In N.K. Denzin \& Y.S. Lincoln (Eds.). Handbook of Qualitative Research (163-187). Thousand Oaks, CA: Sage.
Hampden-Turner, C. \& Trompenaars, F. (2000). Buildning Cross-Cultural Competence. Yale University Press.

Hofstede, G. (2001). Culture's Consequences. Thousand Oaks: Sage.

Hughes, J., \& Sharrock (1997). The Philosophy of Social Research. New york: Addison Wesley Longman.

Kuhn, T.S. (1970). The structure of Scientific Revolutions. Chicago: University of Chicago Press.

Lee, T.W. (1999). Using Qualitative Methods in Organizational Research. Thousand Oaks, CA: Sage.

Lincoln, Y.S. (1990). The Making of Constructivist: A Remembrance of Transformation Past. In E.G. Guba (Ed.). The paradigm dialog. Pp. 6787. Thousand Oaks, CA: Sage.

Lincoln, Y.S., \& Guba, E.R. (1985). Naturalistic Inquiry. Newbury Park, CA: Sage.

Lincoln, Y.S., \& Guba, E.R. (2000). Paradigmatic Controversies, Contradictions, and Emerging Confluences. In N.K. Denzin \& Y.S. Lincoln (Eds.), Handbook of Qualitative Research. Pp. 163-188. Thousand Oaks, CA: Sage.

Martin, P.Y. \& Turner, B.A. (1986). Grounded Theory and Organizational Research. Journal of applied Behavioural Sciences, 22(2), 141157.

May, T. (2001). Social Research: Issues, Methods and Process. MeidenheadUK: Open University Press.

Merriam, S.B. (1998). Qualitative Research and Case Study Application in 
Education. San Francisco: JosseyBass.

Morgan, G. (1997). Images of Organizations. London: Sage.

Neuman, W.L. (2000). Social Research Methods: Qualitative and Quantitative Approaches. Boston: Allyn and Bacon.

Patton, M.Q. (1990). Qualitative Evaluation and Research Methods. Newbury Park, CA: Sage.

Patton, M.Q. (2000). Qualitative Evaluation and Research Methods. Thousand Oaks, CA: Sage.

Remenyi, D., Williams, B., Money, A. and Swartz, E. (1998). Doing Research in Business and Management: An Introduction to Process and Method. London: Sage.

Roco, T.S. (2003). Shaping the Future: Writing up the Method on Qualitative Studies. Human Resource Development Quarterly, 14(3), 343-349.

Rorty, R. (1987). Science as Solidarity. In J.S. Nelson, A. Megil, \& D. Mc.Closkey (Eds.). The Rhetoric of Human Sciences (38-52). Madison: University of Wisconsin Press.

Ruane, J.M. (2005). Essentials of Research Methods: A Guide to Social Science Research. Oxford, UK: Blackwell.
Sarantakos, S. (1998). Social Research (2 ${ }^{\text {nd }}$ ed.). South Yarra: MacMillan.

Sarantakos, S. (2005). Social Research $\left(3^{\text {rd }}\right.$ ed.). New York: Palgrave MacMillan.

Scwandt, T.A. (2000). Three Epistemological Stances for Qualitative Research: Interpretivism, Hermaneutics, and Social Constructivism, in N.K. Denzin \& Y.S. Lincoln (Eds.). Handbook of Qualitative Research (189-213). Thousand Oaks, CA: Sage.

Trompenaars, F. (1993). Riding the Waves of Culture, The Economist Book.

Tsoukas, H. (1998). The world and the world: A critique of representionalism in management research, International Journal of Public Administration, 5, 781-817.

Whiteley, A. (2002). Rigour in Qualitative Research. Working Paper Series 02.01. Perth: Graduate School of Business - Curtin University.

Yin, R.K. (1989). Case Study Research: Design and Method. Newburry Park, CA: Sage.

Yin, R.K. (1994). Case Study Research: Design and Methods. Thousand Oaks, CA: Sage.

Yin, R.K. (2003). Case Study Research: Design and Methods. Thousand Oaks, CA: Sage. 